\title{
Financing mix of residential retirement community development model and risk analysis
}

\author{
Xiaozhuang Yang ${ }^{1}$, Yan Teng ${ }^{2}$, Yongjun Chen $^{2}$ \\ ${ }^{1}$ Harbin University of Commerce, Harbin150028, China \\ 2 Harbin University of Commerce, Harbin150028, China. \\ 294291873@qq.com
}

Keywords: Aging, pension community, financing mix, financing risk

\begin{abstract}
China has also ushered in the climax of aging. China's elderly population is big and rapid growth, how to solve the pension and housing the elderly has become a hot issue. High risk, how to design financing combined to achieve the purpose of reducing the risk is an issue faced by most of the pension community development. In situation of the aging and family structures changing, how to seek the optimal combination of financing in a variety of financing models to achieve the purpose of reducing financing cost and analyzed for its risk.
\end{abstract}

\section{Introduction}

By the end of 2008, China's 65-year-old and older population reached 10,956 people, in 2013 the number of aging population reached 13161 million ${ }^{[1]}$, the ratio increased to $9.67 \%$ from $8.25 \%$, an increase of 1.42 percentage points. By the Figure 1 and Figure 1 shows the number of the aging trend of increased year by year, and the proportion has skyrocketed, and changes in the above figures were indicative of the seriousness of the situation of China's aging population.

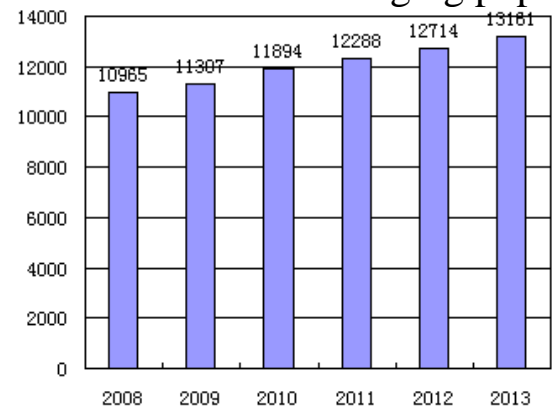

Fig.1 2008-2013 population over the age of 65

\section{The financing of the pension community}

\section{Bank loan}

Bank loans are one of the most common real estate business financing is the most important one. Bank loan financing costs are relatively low, but the amount of bank loans have certain restrictions, are generally not exceed $70 \%$ debt ratio. But the situation was different pension community, the state allocated some land to welfare-based, so the land can not be used as collateral to solve the problem of financing for the real estate business. From our current situation, bank loans are the main sources of financing for real estate companies.

\section{Real Estate Investment Trust}

REITs can effectively solve the liquidity of real estate investments, security issues. effective way to try the product liquidity, but also conducive to investors to provide a variety of new products ${ }^{[3] \text {; }}$ Real Estate Investment Trust in the choice of investment projects, according to the project's own characteristics to choose ${ }^{[4]}$. Correspondingly, management, mode of operation and the different portfolios to reduce investment risk. Development of real estate investment trusts have important way to improve the corporate finance and promote the development of the market. 


\section{Equity financing}

Qualification offering not only have strict requirements for listing process is very complex, and issue stock market also need to pay a higher cost ${ }^{[5]}$. Therefore, many real estate development companies through equity financing not to meet its funding needs. However, issuance of common stock is no fixed interest, compared with other financing, risk can not be servicing does not exist, therefore equity financing risk is relatively small, but also through equity financing can enhance visibility.

\section{The retirement community financing portfolio and risk analysis}

\section{The cost of financing the econometric model}

Financing costs can be expressed in both absolute and relative measurement methods, the relative number of measurement methods for a variety of financing methods to compare the cost of financing the measure, specifically refers to funds raised financing costs and actual ratio. If the cost of financing is represented by $\mathrm{K}$, financing charges I said that the total amount of financing by $\mathrm{P}$, financing costs an F, then the financing costs of the econometric model indicates the following equation (1):

$$
\mathrm{KIPF} /(-)
$$

Under different financing methods, the above formula I, P, F has a different meaning, in order to make the reader a better understanding, the following econometric model commonly used for financing under the analysis is derived:

The cost of issuing equity financing econometric model

By preferred stock to raise funds not only to pay financing costs but also regular payment of dividends, and because dividends paid after income tax has no tax effect, then the model (1) the cost of financing preferred shares available measurement model

$$
\text { KPE } D_{0} /(1-)
$$

Where $\mathrm{D}_{0}$ is the total annual dividend, $\mathrm{P}$ par value preferred stock, $\mathrm{f}$ is financing rate preferred shares issued.

\section{The issuance of bonds financing cost measurement model}

Issuance of bonds and bank loans compared to these two financing methods, different financing bonds in addition to the amount due to the different distribution methods $\mathrm{P}$ obtained, other factors influence the cost of financing the measure is completely similar. Under normal circumstances the following equation (3) metering bond financing costs.

$$
K_{b}=i(1-t) /(1-f)
$$

Where the financing costs for the bond rate, the interest rate for the bond.

If the bonds are issued at a discount or a premium, you can use the following formula (4) Bonds econometric model

$$
\left.\mathrm{KbI}+\mathrm{B} \quad\left(o_{0}-B_{1}\right) / n\right](1-t) /\left(B_{1}-F\right)
$$

Bonds with a face value of which represents B0, B1 with the issue price.Said the bond repayment period is represented by $\mathrm{n}$, financing costs of $\mathrm{F}$ bonds, said bonds with annual interest I represent.

\section{A combination of different financing and financing costs of metering applications}

According to the basic econometric model of financing costs (1) and deduced specific econometric model, we can easily get a variety of financing methods in a single financing costs. But in a variety of financing methods, in order to find the optimal combination of financing, the need to calculate a single financing costs, using the weighted average mathematics metering method to calculate the comprehensive financing cost.The company financing combination of costs can be expressed as:

$$
K K W V
$$

Therefore, the analysis step to find the optimal combination of corporate financing as follows:

(1) consists of the econometric model (1) to derive specific relevant financing model to measure each of the financing cost of financing; 
(2) Calculate the ratio of financing under a single gold of the total amount of financing of financing;

(3) calculate the cost of financing real estate companies under different financing mix based econometric model (5);

(4) the size of the financing costs of the financing mix to compare different programs to choose the best combination of program financing.

\section{Project profile}

$\mathrm{Xx}$ company plans to develop the construction of a new retirement community housing project, which includes residential home, senior citizen centers, service centers and recreational center, a residential, pension, leisure and entertainment multi-functional residential community endowment, the project budget investment of 2 billion yuan, 300 million yuan of its own funds, the company is now the main financing channels, including bank loans, bonds, issue of shares, real estate investment trusts. According to the premises of the financing conditions of the industry, feasibility studies and other relevant laws and policies and investment projects of national data, for each financing estimated financing costs and the maximum amount of financing amount (see Table 1). Find the best $\mathrm{xx}$ financing company.

Table 1 financing costs and financing limits under different financing

\begin{tabular}{c|c|c|c}
\hline financing channel & $\begin{array}{c}\text { Estimated cost of } \\
\text { financing } / \%\end{array}$ & $\begin{array}{c}\text { Financing quota/ } \\
\text { Billion yuan }\end{array}$ & Special restrictions and remarks \\
\hline bank loans & 5.7 & 7 & Required debt ratio is not higher 65\% \\
\hline Creditor's rights & 7 & 8 & Own funds at least 30\% \\
\hline Real estate fund & $13 \sim 14$ & 3 & $\begin{array}{c}\text { 200 million yuan in the following } 14 \%, \\
\text { Equal to or exceeding } 13 \%\end{array}$ \\
\hline Shares & 9 & 2 & \\
\hline Real estate & 11 & 1 & \\
\hline
\end{tabular}

Meaning of the questions was: This real estate company's financing are two major categories: liabilities and equity. Financing liabilities include bank loans and bonds. Equity financing for the issue of shares, real estate funds and real estate investment trusts. There table 2 provides the financing costs liabilities are less than the equity financing. We want as much as possible to finance through bank loans and bonds. There are three types of financing in the equity class: stocks, funds and real estate trusts.

This real estate development company a total investment of 2 billion yuan, 300 million yuan of its own funds, and the remaining 1.7 billion yuan in Table 1 through five channels to obtain financing, but also because of the special restrictions and regulations Remarks in the debt ratio no higher than $65 \%$, so the bank loans and the issuance of bonds not more than 1.3 billion, real estate funds, stocks, real estate investment trusts and financing of not less than 400 million yuan.

(1) lower the maximum cost of financing debt select category of financing, there are two options to choose from, Option One: to maximize the choice of the lowest cost financing bank deposits 700 million, and then select the bond financing 600 million. Option Two: Select the relatively low cost of financing debt financing of 800 million, but at the same time select bank deposits 500 million.

(2) The remaining 400 million in equity financing, first select the low financing costs 200 million equity financing, then the rest of the equity financing scheme has two options, Option One: 100 million real estate investment trust, and select 100 million real estate fund. Option Two: just choose the financing costs :higher real estate fund 200 million.

(3) The above analysis leads to a combination of four kinds of financing options are available.

Table 2 Under the combination of different financing options financing costs mete

\begin{tabular}{c|c|c|c|c|c|c}
\hline Plan & loan & bond & Shares & The real estate trust & Real estate fund & combination kn/\% \\
\hline W1 & $7 / 17$ & $6 / 17$ & $2 / 17$ & $1 / 17$ & $1 / 17$ & 7.35 \\
\hline W2 & $7 / 17$ & $6 / 17$ & $2 / 17$ & 0 & $2 / 17$ & 7.41 \\
\hline W3 & $5 / 17$ & $8 / 17$ & $2 / 17$ & $1 / 17$ & $1 / 17$ & 7.5 \\
\hline W4 & $5 / 17$ & $8 / 17$ & $2 / 17$ & 0 & $2 / 17$ & 7.55 \\
\hline
\end{tabular}


Option One W1: bank deposits 700000000 + bonds 600000000 + shares 200000000 +REIT 100000000 + real estate fund 100000000 .

Option Two W2: bank deposits $700000000+$ bonds $600000000+$ real estate fund 200000000 +shares 200000000 .

Option Three W3: bank deposits 500000000 + bonds 800000000 + real estate fund 200000000 +shares 200000000 .

Scenario four W4: bank deposits 500000000 + bonds 800000000 + shares 200000000 + real estate investment Trusts $100000000+$ real estate fund 100000000 .

From the above analysis, the optimal solution can be drawn one scheme, namely the best financing options for the project: 700 million bank deposits, bonds issued 600 million, 200 million shares, 100 million real estate investment trusts and real estate funds 100 million. By optimizing the financing mix both solutions can reduce financing costs, and can disperse market risks.

(c)Risk analysis about combination of financing

It introduces a measure of financial risk portfolio variance process, risk financing mix is usually measured in with its expected revenue variance[8]. The size of the variance can be expressed size of the risk, because the risk is from the uncertainty of the future, this uncertainty would affect the size of the expected return, the greater the volatility, the greater the uncertainty; the smaller the volatility, the more easy to determine its true value. The role of the variance is a measure of the volatility of the average size of a number of series, so you can assess the degree of risk financing variance portfolio. Calculated as follows:

$$
\sigma_{p}^{2}=\sum_{i}^{n} \sum_{j}^{n} W_{i} W_{J} \sigma_{i} \sigma_{j} p i j=\sum_{i}^{n} W_{j}^{2} \sigma_{j}^{2}+2=\sum_{i>j}^{n} \sum^{n} W_{i} W_{j} \sigma_{i} \sigma_{j} p_{i j} \cdots \cdots
$$

Where, $\sigma_{p}^{2}$ — The variance of portfolio returns; $W_{i}$ - Right i kind of heavy financing; $W_{j}$ Right $\mathrm{j}$ kind of heavy financing; ${ }^{\sigma_{i}}$ ——Standard i seed financing percentage deviation of returns; ${ }^{\sigma_{j}}$ - - Standard $\mathrm{j}$ kind of financing the difference between the percentage of income; $p_{i j}-$ The correlation coefficient financing $\mathrm{i}$ and $\mathrm{j}$ of financing benefits between.

Among them, ${ }^{p_{i j}}=\sigma_{i j} / \sigma_{i} \sigma_{j}, \sigma_{i j}$ represents earnings covariance between $\mathrm{i}$ and $\mathrm{j}$. Calculated by the above formula to determine the size of its variance. Its financing portfolio greater the variance, the greater the risk of financing; on the contrary, the risk is smaller.

\section{Summary}

Retirement community is the product of the birth of the next wave of aging, the development of China's pension community is not mature, it is essential to explore and improve. Although the retirement community has a large market potential, but developers need to invest a lot of money, there are some problems in the management, operation, etc., so developers to do to reduce the risk, ready to take risks, to broaden the financing channels at the same time, with a reasonable financing ratio, lower financing costs and control the financing risk that the development and construction of the project can proceed smoothly.

\section{Acknowledgement}

In this paper, the research was sponsored by the 2015 Harbin University of Commerce graduate innovative research projects (project number.YJSCX2015-386HSD).

\section{References}

[1] National Bureau of Statistics. National Economic and Social Development Statistics Bulletin People's Republic of China.

[2] Du Zhimin, Teng Meng study the operating mechanism and the development prospects of the pension community. Northwest University .2012 (5). 
[3] Zhang Zhengyi. On Present Situation. Market Modernization .2006 (3) of the current real estate financing

[4] Song Chunlan research financing real estate development enterprises. Financial management .2015 (1).

[5] Chen Qianqian. Talking about China's commercial real estate financing model. Times Financial .2015 (2). 